University of Nebraska - Lincoln

DigitalCommons@University of Nebraska - Lincoln

\title{
Blue-Collar Discourses of Workplace Dignity: Using Outgroup Comparisons to Construct Positive Identities
}

\author{
Kristen Lucas \\ University of Nebraska-Lincoln, kristen.lucas@louisville.edu
}

Follow this and additional works at: https://digitalcommons.unl.edu/commstudiespapers

Part of the Organizational Behavior and Theory Commons, Organizational Communication Commons, and the Work, Economy and Organizations Commons

Lucas, Kristen, "Blue-Collar Discourses of Workplace Dignity: Using Outgroup Comparisons to Construct Positive Identities" (2011). Papers in Communication Studies. 13.

https://digitalcommons.unl.edu/commstudiespapers/13

This Article is brought to you for free and open access by the Communication Studies, Department of at DigitalCommons@University of Nebraska - Lincoln. It has been accepted for inclusion in Papers in Communication Studies by an authorized administrator of DigitalCommons@University of Nebraska - Lincoln. 


\title{
Blue-Collar Discourses of Workplace Dignity:
}

\section{Using Outgroup}

\section{Comparisons to}

\section{Construct Positive}

\section{Identities}

\section{Kristen Lucas}

University of Nebraska-Lincoln

\begin{abstract}
People generally possess a strong desire to construct positive, dignified work identities. However, this goal may be more challenging for some people, such as blue-collar workers, whose occupations may not offer qualities typically associated with workplace dignity. Interviews with 37 people from a blue-collar mining community reveal three central identity discourses about workplace dignity: All jobs are important and valuable; dignity is located in the quality of the job performed; and dignity emerges from the way people treat and are treated by others. Participants communicated these themes by backgrounding their own occupations and drawing comparisons between two outgroups, low-status, lowpaid dirty workers and high-prestige, white-collar professionals. Implications for understanding how identity work is negotiated and for managing a blue-collar workforce are explained.
\end{abstract}

Keywords: dignity, identity work, self-categorization theory, dirty work 
Work is a central and significant facet of modern life (Ciulla, 2000) and a direct and indirect source of meaning and self-worth (Cheney, Zorn, Planalp, \& Lair, 2008). It should come as no surprise then that people possess a strong desire to construct positive identities related to their participation in work activities and/or membership in work-based organizations (Dutton, Roberts, \& Bednar, 2010). While there has been considerable attention paid to identity negotiations and tensions within the context of active threats such as globalization pressures (Ailon-Souday \& Kunda, 2003; Pal \& Buzzanell, 2008), organizational change (Ashcraft, 2005; Pepper \& Larson, 2006), and workplace bullying (Lutgen-Sandvik, 2008), with the exception of gender (Jorgenson, 2002; Lucas \& Steimel, 2009), there has been much less attention paid to identity and identity work in the face of nonacute, yet salient and persistent, challenges to crafting positive work-related identities.

One possible way in which a positive identity can be constructed is through finding a particular kind of meaningfulness in work: dignity (see Cheney et al., 2008; Lamont, 2000). Yet achieving a fully dignified work experience - and by extension, a positive, dignified identity - may be more challenging for some, especially those whose occupations may not offer typical qualities associated with workplace dignity (e.g., status, autonomy, participation; see Hodson, 2001). The purpose of this study is to gain insight into how blue-collar individuals talk about dignity in the workplace and, in particular, how they engage in constructing positive work identities imbued with dignity. The dignity discourses that emerge from their talk should shed light on understanding their social identity negotiations and experiences of (in)dignity at work. Furthermore, these findings likely have important practical implications for highlighting ways to enhance the experience of workplace dignity for blue-collar workers. To situate the study, I first provide an overview of workplace dignity. Then I sketch a rationale for using an identity work and self-categorization theory lens to understand the identity negotiations of blue-collar workers. Finally, I present a brief description of the mining industry, particularly as it is related to (blue) collars and social class.

\section{Dignity at Work}

Dignity is a central thread that runs implicitly throughout several prominent lines of current organizational communication scholarship: civility (Sypher, 2004), employee emotional abuse (Lutgen-Sandvik, 2006), and sexual harassment (Keyton, Ferguson, \& Rhodes, 2001), to name only a few. At its most basic denotative level, dignity refers to inherent worth and value and/or being deserving of respect. Placed into a workplace or 
career context, it means the recognition of the inherent worth and value of organizational actors. Communication plays a central role in the accomplishment of dignity - from dyadic interactions to communicatively (re)produced organizational cultures and structures to macrolevel discourses (Lucas, 2010). Dignity is an important conceptual focal point for research and, perhaps more important, an essential requirement for meaningful work (see Cheney et al., 2008; Ciulla, 2000).

A central dignity-focused theme within current organizational communication and related research is that dignity is more difficult to achieve for members of subordinated groups than for members of dominant groups. From a difference perspective, social identity markers such as race, class, and gender can present unique challenges to achieving dignity at work. For example, Allen (2000) describes the challenges faced by women of color as they fight a beneficiary of affirmative action stereotype that calls into question their competence and value. Meares et al. (2004), in their study of people mistreatment, found that subordinated organizational members - whether by sex, race, education level, or organizational position - were more likely to have muted narratives of abuse than more privileged members. From a gender perspective, Tracy and Scott (2006) argue that firefighters' masculine jobs (i.e., jobs that require physical strength and bravery) are a resource for creating highly esteemed occupational identities; whereas, corrections officers' feminized job tasks (e.g., feeding inmates, providing care) stigmatize that male-dominated occupational group and serve as a hindrance to crafting dignified identities.

Challenges to dignity also can result from the positionality of certain occupations in relation to organizational others. For example, Lawless and Moss (2007) explain that although dignity is a central tenet in nursing care, the dignity needs of nurses often are subordinated to those of patients. The authors caution about burnout and other negative consequences when nurses are expected to deliver dignity but receive little, if any, in return (see also McGuire, Dougherty, \& Atkinson, 2006). In another context, Korczynski (2003) assessed the emotional labor in frontline customer service jobs. He explains that when companies privileged a customer sovereignty position, telephone customer service representatives were exposed to repeated and intense disrespectful interaction because of their subordinated role to customers. Even in the face of verbal insults and rude treatment, employees were instructed to empathize with customers and were forbidden from commiserating with their peers.

Materiality also can influence the experience of dignity at work. Berg and Frost (2005) demonstrated that material conditions (e.g., adequate staffing and resources, access to training) had a significant impact on whether low-paid, low-status hospital employees perceived dignity at work. Purser (2009) describes the ways that Latino immigrants, who fiercely compete 
on curbsides for precarious and low-wage day jobs, engaged in gendered boundary work to maintain self-esteem in the face of poverty and find dignity in their job-seeking practices. Even highly skilled, well-paid workers are not immune to effects of indignity at work. Dufur and Feinberg (2007) detailed how National Football League recruits experience regular affronts to their dignity - comparing at times the draft process to the slave tradebecause of the power imbalance produced by artificially restricted labor markets for professional athletes vying for lucrative contracts.

Finally, social stigma can complicate the experience of workplace dignity. Newman's (1999) ethnography of Harlem's fast-food industry demonstrates that workers in low-prestige "McJobs" suffered social stigma that exacerbated their experiences of indignity at work. Employees frequently dealt with disrespectful customers who felt entitled to denigrate the low-wage, low-status workers by cursing and hurtling insults at them. Ashforth and Kreiner (1999) also explain how dirty workers who are stigmatized by physical, moral, or social taint-especially those who lack a status shield - have to work hard to construct a positive identity when outsiders view their work as repugnant. In sum, the implicit threads of dignity that run throughout prominent lines of organizational communication inquiry and the emerging lines of dignity research in other disciplines point to the importance of dignity at work, particularly for people who are materially and/or discursively subordinated.

Because they are located at the intersection of several subordinated identities, blue-collar workers can provide important insights into the experiences and meanings of dignity at work. In terms of positionality, bluecollar workers often are placed in powerless organizational positions as they do not control the means and modes of production (as compared to managers, owners, etc.; Zweig, 2000). From a material standpoint, they tend to have less access to stable and secure resources over time, which materially disadvantages them and further limits their agency on the job (Mishel, Bernstein, \& Shierholz, 2009; Perrucci \& Wysong, 2003). Finally, they often are stigmatized through media portrayals that present them as uneducated, inarticulate, and drunk (Alper, 2005), by social stratification systems that evaluate their occupations among the lowest in terms of prestige (Gilbert, 2008), by physical conditions that mark their jobs as tainted (Ashforth \& Kreiner, 1999), and by discourses that deem their jobs as somehow not "real" (Clair, 1996).

\section{Communicating Social Identity}

The intersection of blue-collar occupations and workplace dignity can be understood through a lens of identity, which has become quite a robust 
field of research in recent years (Alvesson, Ashcraft, \& Thomas, 2008; Scott, 2007). To begin, Alvesson and Willmott (2002) explain that people "continuously engage in forming, repairing, maintaining, strengthening or revising the constructions that are productive of a precarious sense of coherence and distinctiveness" (p. 626) via a process they call identity work. Identity work is a complex and inherently communicative process in that it is a negotiation of simultaneously held identities (e.g., race/ ethnicity, gender, social class) and individualized meaning-making in interaction with people and systems (Alvesson et al., 2008; Hogg, 2006; Scott, 2007).

Alvesson and Willmott (2002) argue that individuals are more likely to engage in active identity work when encounters with others raise worry and/or self-doubt. For instance, Ashforth and Kreiner (1999) describe different ways dirty workers were able to shift occupational ideologies (i.e., reframing, recalibrating, and refocusing) to promote a positive social identity despite their work being regarded as repugnant by society. They posit that dirty workers communicate within their own work groups to establish strong work cultures that counteract the social stigma and taint attached to their work. Their daily discourses transmit and reinforce a system of shared values that serves to construct a positive occupational identity. Similarly, Gibson and Papa (2000) demonstrate that factory workers rallied around the pride associated with their strong work ethic. Lucas and Buzzanell (2004) found that underground miners shared occupational narratives in which inner determination was held up as a central organizational value and measure of success that was used to (re) value the work they performed. Even though these articles ultimately portray the creation of positive identities, these blue-collar workers' discourses emerged as a response to a tendency to be denied affirmation from larger society.

Dutton et al. (2010) describe positive identity construction as an evaluative and effortful process that encompasses individual, relational, and social identities. That is, positive identity not only is derived from a sense of personal distinctiveness, but individuals also must contend with the value attached to the social categories to which they belong. These values may be real or perceived and may be imposed by the self or by others inside or outside of any given social category. Therefore, self-categorization processes must be considered.

Self-categorization theory, which is an extension of social identity theory, is based on the belief that self-concept comprises personal and social identities (Turner \& Oakes, 1989). It has at its core the processes of categorization and comparison as the means for psychological group formation. Therefore, in addition to defining who the individual is, these social identities also define who the individual is not (Turner \& Oakes, 1989). In 
other words, based on social similarities and differences, an individual is defined as a member of some social categories (i.e., "ingroups") and as a nonmember of others (i.e., "outgroups"). Ashforth and Mael (1989) explained that these social classifications provide people with a systematic way of understanding the social environment and locating and defining themselves and others within that environment.

A key principle of self-categorization theory is the belief that individuals desire a positive status and distinctiveness for themselves and a positive identity for their own social groups (Turner \& Oakes, 1989). Because social identification is largely "relational and comparative" (Ashforth \& Mael, 1989, p. 21) - meaning that individuals define themselves relative to people in other social categories - the construction of positive identity necessarily relies on social comparison and intergroup competition. Based on this principle, it is assumed that members of lower-status groups will attempt to identify with higher-status outgroups. Turner and Oakes explain that "a negative social identity, low social status, should naturally tend to induce movement out of the subordinate group" ( $p$. 235). Yet there is ample evidence that many people choose to retain their subordinated group identities. In these cases, individuals often engage in intergroup comparisons that bolster perceptions of their ingroup and discount comparative outgroups.

Social comparisons-downward ones in particular-are well-documented in studies of working-class workers. For example, Ashforth and Kreiner (1999) explain that subordinated dirty workers engage in downward social comparisons as one way of promoting a positive social identity and framing their own occupation as superior to a lower-status group's occupation (e.g., a factory worker saying, "At least I don't have to clean toilets for a living"). In empirical studies, Zoller (2003) shows how autoworkers who were repeatedly exposed to on-the-job health and safety risks favorably compared themselves and their working conditions to fast-food workers, citing their skill, adaptability, and strong work ethic as the grounds for their higher wages and more intrinsically challenging work. Lamont (2000) goes even further when demonstrating the complex social comparisons in which working-class men engage as they "search for respect and alternative spheres of worth" (p. 101). She explains that ingroup-outgroup comparison, which she calls "assessing people above and people below," is a well-documented facet of working-class identity work. In particular, working-class men make comparisons that simultaneously reject and accept "people above" and distance themselves from "people below" (p. 101).

Based on the prevalence of ingroup-outgroup comparisons in research on working-class and blue-collar workers, self-categorization 
and social comparisons appear to play a central role in identity work negotiations. Therefore, this study is guided by the ways in which social identity processes of categorization and comparison are used as the basis for performing identity work aimed toward constructing a dignified identity.

\section{Mining, Collars, and Class}

Mining often is viewed as the quintessential blue-collar occupation. It is a dirty and dangerous job with a long history. Although the U.S. mining industry employs only a fraction of the people it once did, there currently are 741,000 men and women who work in mining and extraction industries, 553,000 of whom work in blue-collar positions (Bureau of Labor Statistics, 2010). These laborers earn an average wage of \$24 per hour. Despite significant advances in safety over the years, mining remains a dangerous job. It has one of the highest occupational fatality rates, with approximately 25 of every 100,000 employees being killed on the job each year.

Miners generally identify themselves as blue-collar, privileging their physical strength, work ethic, and commonsense over "book smarts" and tasks more commonly associated with white-collar work. Even miners in the current study who had earned college credits (or, in a few cases, college degrees) self-identified as blue-collar. Regardless of their education level, these workers get dirty, rely heavily on their physical strength, and sit on the opposite side of management at the bargaining table. However, determining social class is much more complicated than simply identifying the color of a collar.

When social class is conceived in terms of income and consumption, miners fall easily into the middle class. Their semi-skilled jobs earn them fair wages that provide for a comfortable, middle-class lifestyle. However, other definitions of social class paint a different and more nuanced picture. Social class can be conceived of in terms of capital-worker relationships (Zweig, 2000), as the stability of access to resources over time (Perrucci \& Wysong, 2003), and as a set of shared cultural values (Kaufman, 2003). In these instances, miners do not fit middle-class definitions. First, miners implicitly understand that management controls the means of production, sets the quotas, and signs the paychecks. Second, despite earning a middleclass wage, miners' access to that wage is quite unstable due to the volatility of the mining industry. Layoffs, strikes, and seasonal slowdowns cast doubt on the assurance of the next paycheck. Longer periods of downturn can drain savings accounts and immerse 
families deeply into debt. Third, their blue-collar values and lifestyles differ from their middle-class counterparts. They generally prefer hunting and fishing over golf, beer over wine, and plain talk over polished language. For these reasons, miners in this study also proudly and unequivocally identified themselves as members of the working class.

\section{Method}

The participants for this study were members of a small, blue-collar mining community in the mid-Western United States. The first group of participants were men who had life-long careers in the mines $(n=21)$. All were either retired or within a few years of retirement at the time of the interviews. The second group comprised the miners' wives $(n=16)$. Their occupations included stay-at-home parenting, food service, secretarial work, retail sales, nursing, teaching, and blue-collar labor. They ranged in age from their mid-50s to early $80 \mathrm{~s}$.

I conducted in-depth, semistructured interviews with participants at the site requested by them (e.g., homes, restaurants, workplaces). Three interviews were conducted by phone. Phone interviews revealed information as rich as in-person interviews. The majority of participants were interviewed as a couple, per their request. The interviews focused on work-related values and attitudes and experiences related to deindustrialization. One question specifically asked about dignity ("What kinds of work do you think have the most dignity?"). The open-ended structure was chosen to allow participants to answer the question in their own way without leading them. Interviews were transcribed and verified against the original recordings, and all names and identifiers were replaced with pseudonyms. In total, transcription yielded more than 475 pages of single-spaced text.

For the analysis, I began by selectively coding the data, using qualitative data analysis software to facilitate retrieval and increase analytic rigor (Miles \& Huberman, 1994; Weitzman \& Miles, 1995). As the first step, I winnowed the data from the complete transcripts to a smaller subset of data that represented textual units relevant to dignity and dignified work identities (Wolcott, 1994). These textual units included every explicit mention of the word dignity. Additionally, they included conceptually linked concepts such as those related to stigma and dirty work (Ashforth \& Kreiner, 1999), real jobs (Clair, 1996), and respectful interaction (see Korczynski, 2003). The smaller data set totaled 28 pages of single-spaced text. I then conducted several rounds of open coding and memoing to examine, interpret, and test the winnowed data. The data 
were sorted and analyzed using thematic analysis techniques (Lindlof, 1995). Specifically, Owen's (1984) criteria of recurrence (same meaning, different wording), repetition (same wording), and forcefulness (nonverbal cues that stress or subordinate words and phrases) were used to identify themes.

A caveat is needed here. The textual units used for analysis were taken from interviews instead of naturally occurring discourses. Therefore, it raises the concern that dignity may have been relevant only insofar as participants were responding to a direct question. Also, the data may reflect some biases (such as social desirability effects) that may not be present in everyday discourses outside of interviews. However, given the prevalence of spontaneous talk of dignity throughout the interviews and not solely in response to direct questioning, the passion with which participants responded (as emphasized through their pitch, volume, facial expressiveness, gesturing, etc.), and the consistency in both the content and the pattern of participants' responses, these utterances appear to be highly salient, mutually agreed upon, and consistently communicated. Therefore, they are taken and treated here as naturally occurring, authentic discourses.

\section{Findings}

The interviews revealed three central content themes related to dignity at work: (1) All jobs are important and valuable, (2) dignity is based on the quality of the job performed and not the status of the job, and (3) dignity emerges from the way people are treated and treat others in their day-today interactions. In addition to the content of their discourses, their discourses also followed a particular pattern. That is, almost every explanation or anecdote used to illustrate participants' respective positions included a juxtaposition of high-status and low-status workers. Examples include millionaires versus garbage collectors, "professional career" versus "hanging off the back of a garbage truck"; "some highfalutin person in a white shirt and suit" versus "a guy coming home dirty, greasy, dirt under the fingernails"; and a cardiologist versus "Joe Blow doing some kind of general labor." Notably, participants were not prompted in any way to make comparisons, nor were they asked about specific occupations. In short, these high-status-low-status comparisons occurred frequently without any prompting. Moreover, what was missing from their discourses was any mention of mining jobs. This conspicuous absence was noted across all the themes. 


\section{All Jobs Are Important and Valuable}

The first theme that emerged focused on the importance and value of all jobs, regardless of social status or occupational prestige. Participants drew comparisons between low- and high-status occupations to demonstrate the value of each job in achieving organizational goals and benefiting society in general. For example, Helen juxtaposed the careers of ditch diggers and the president to explain that all jobs play an important role in society:

Whether you're digging a ditch or the president, each job has its own kind of dignity. You know, somebody has to do all the jobs. ... There's a lot of real educated people that just as soon dig a ditch in a perfect line than go put a suit and tie on. I don't think any one has any more dignity than the other. I think they all have it. I mean we need all the jobs to live. When somebody doesn't dig the ditch, we don't have the sewer.

In this example, Helen draws upon the dirty work of ditch digging to contrast it to the "suit and tie" wearing president. In her explanation, she emphasizes the necessity of both jobs, which was a common theme. Noreen offered a similar comparison between hotel housekeeping staff and executives:

I think any necessary work that people do is dignified. If we didn't have people to clean toilets, where would the rest of us be? So I believe that that is just as important a job as the high executive. Except one earns a lot and one earns a little. But they're equally important in their own way. ... And the kind of clothes shouldn't make a difference either. Because you wear the clothes suited to the type of work you do. If it's a maintenance uniform, you wear it. You know, like a hotel maid or whatever like that. You know, they're not going to have a fancy business suit, but their work is just as important. We'd be lost without them.

Gary and Gail, a married couple, collaboratively summarized some of the tensions between the juxtapositions. Although neither one ever worked as a garbage collector or ditch digger, they acknowledged the stigma that may be attached to those particular occupations by making a less direct comparison to the kind of work that requires a college degree or "pays $\$ 20$ more an hour": 
Gary: In this life, you've gotta have garbage men, you gotta have ditch diggers.

Gail: Yeah, they're all real jobs.

Gary: If they're not going to have real jobs just because they didn't go to college.

Gail: Just because someone makes $\$ 20$ more an hour than I do.

Gary: Who's going to dig ditches? Who's going to pick up your garbage?

Gail: That's a real job.

Across all these excerpts, like the dirty workers in Ashforth and Kreiner's (1999) study, participants foregrounded the value of the work performed and backgrounded the dirtiness of low-status jobs. By providing a sharp contrast between the dirtiest of work (e.g., cleaning toilets, digging sewer ditches) to some of the cleanest and most esteemed occupations (e.g., president, corporate executive), they carved out a place where all occupations could be respected and valued for their contribution to society or, at a minimum, to the organization's bottom line. Furthermore, they intimated some of the stigma that may be attached to work that is low paid and low skilled.

\section{Dignity Is Based on Quality of Work Performed}

The second content theme found throughout the interviews centered on the quality of work performed and people doing their "best work." This quality marker was a central aspect of how participants defined dignity. Once again, this theme was illustrated with examples that juxtaposed high- and low-status workers explicitly and implicitly. As in the previous theme, garbage collectors again were a favorite low-end occupational group used for drawing comparisons. Carl used them as an example to explain that dignity is about doing a job "right":

If you like the job and you do it right, you could be the guy that goes by collecting garbage every day. There's dignity in that job, just as well as any other job as far as I'm concerned. That's how I look at it. Just because you're a millionaire don't mean you're anything.

Another regular comparison group was fast-food workers. Elizabeth talked about quality in terms of "working hard" and "doing their best": 
My parents taught me that any job was - if you worked hard - was a good job. Even if you flopped a Whopper, if you did it honestly, it was a good job. Just that they're, they're working as hard as they can and doing the best they can is a real job. Be it shoveling shit, digging a ditch, flopping a Whopper, or being a lawyer. That's a real job.

High-status and low-status comparisons were not always explicit. Allen is one participant who drew upon an implicit comparison. In this case, he discusses dignity as the quality of "doing your job well" and uses several dirty jobs to make his point:

Dignity is just how you do your job. If you do your job well. I don't care what kind of job you do. If you do your job and you do it well, what else is there? I mean we need people to do this and that, eh. No matter what it is. If you walk into a restroom in an airport, and there's a guy in there cleaning the restroom and it's nice and clean, that's pretty much dignity. I don't care what kind of work you do, if you do it right, you know, do it good, that's dignity. I don't care if I'm shoveling shit in a trench or whatever. No, I respect anybody that's working. I don't care what kind of work they're doing. If they're working and they got a good job and they're doing a good job, yeah, I respect that.

In these comparisons, the takeaway point is that in any job undertaken there can be quality work done. Although a slight nuance, it also indicates that so-called unskilled jobs can be performed with varying degrees of quality, acknowledging there is a certain amount of skill required and that there are quality markers for any job " nice and clean" restrooms, "flopping a Whopper honestly," and digging a ditch in a "perfect line"). These discourses pointed to a level of care, commitment, and competence that may otherwise be invisible to people unfamiliar with the specifics of particular low-status jobs.

\section{Dignity Is Based on the Way People Are Treated and Treat Others}

The final content theme in participants' talk was based on respectful interaction. This theme surfaced in a variety of ways, from criticizing those who were not respectful to praising those who were. At its core were the ways in which people treated and were treated by others. In response to 
a question about dignity, Sam summed it up by saying, "Just be decent to everyone, that's all." Sharon explained the importance of respect by comparing waitresses and teachers:

I think if you're proud of what you do, that's a dignified job. A waitress can be dignified if she is happy in what's she's doing and if she treats people right, and people treat her right. I mean, teaching should be a dignified job. But I think it's a thankless job because the kids give the teachers - there's no respect out there.

What distinguishes this theme from the others is that whereas the previous juxtapositions were depersonalized and abstract, these comparisons were much more personal and specific. Furthermore, the anecdotes shared often focused on interactions that emphasized status differences and revealed the sting of social stigma. One story in which a social status difference was highlighted in interaction was told by Linda, who worked as a medical office clerk. In the story, she juxtaposed her job as a clerk with doctors, lawyers, and the teacher who triggered this event:

I worked with a woman who was a teacher [had a teaching degree]. And her husband was a teacher. And of course we worked for doctors. And she told me one time that because they were teachers and are doctors and whatever that we should automatically respect them. And I told her, "Just because you're a lawyer, a teacher, a doctor, doesn't mean that I automatically should respect you." ... You earn your respect from people. Just because you're a doctor doesn't mean you're the most wonderful person in the world.

The hurt inflicted by this interaction was evident from how Linda continued with her story:

I don't think putting a "Dr." in front of your name or a lawyer, an attorney's signature after your name automatically puts you in a different class than anybody. I think that everybody's equal. You don't automatically have to respect someone or think they're above you just because they have the degrees. The girl I worked with, she was a teacher. But she was making less money than me working at [the medical office as a clerk]. But she thought that I should automatically respect her or think that she was better because she had a degree and I don't. 
Even though this story was framed as the coworker demanding respect because of her degree, the unspoken flip side is that her comment implied that Linda and other non-degree holders do not deserve the same level of automatic respect. Therefore, it was an anecdote about status differences being highlighted, if not exaggerated.

Another way in which status differences were highlighted is implicit in excerpts that discuss the lack of power working-class people have compared to executives who run organizations. Rita says the following about "the corporate person who's out to increase their wealth and screw the employees below them":

I think even the burger guy at McDonalds, if they go to work and they're good to the customers and they show up on time, there's a certain amount of dignity to that job. And I think in any aspect. Some are a little more white-collar, some are a little cleaner. But you can be a corporate executive that is bent on the bottom-line. And you may have the best house, you may look good in a suit, but you can layoff people and not care. There's no dignity in that.

These juxtapositions are more raw than the examples in the previous themes. In many cases, they were cautionary tales in which the antagonist (usually from the higher-status group) had disrespected the protagonist from the lower-status group. In these examples, a medical office clerk with a college degree put herself above an occupational peer without a degree. Corporate executives "layoff people and not care" and "rip off" presumably working-class people who depend on their jobs to make a living. Therefore, respectful interaction consists of more than just the politeness of dyadic interactions. Instead, indignity is characterized by a deeper disrespect stemming from acting upon and emphasizing intergroup status differences and communicating in ways that devalue the category to which lower-status workers belong.

\section{Discussion}

This study reveals important insights into the experiences of and meaning-making in blue-collar identity work. Although participants rarely talked directly about themselves or their occupations, they revealed three key issues for blue-collar workers seeking to experience workplace dignity: All work is valuable and important, dignity is based on quality of work performed, and dignity is manifested in how people interact with one another. These content themes were not mutually exclusive and of- 
ten appeared in simultaneous and overlapping ways. Yet these themes were manifested in a markedly uniform pattern. That is, participants contrasted high-status and low-status occupational groups to make their values and beliefs about work known. Implications for both the pattern that these discourses followed (i.e., the juxtapositioning of high-status and low-status outgroups) and their content themes are outlined below.

\section{Implications of Juxtapositioning}

The most striking aspect of participants' talk was what was absent from their discourse: any mention of mining work and scant attention at best to semiskilled blue-collar jobs. Instead of calling upon their own experiences, participants uniformly juxtaposed high-status and low-status occupations when describing dignity. And to reiterate, there were no prompts to participants asking them about particular occupations or to draw comparisons. Given that there were no prompts and given the prevalence of these comparisons, this discursive pattern has important implications, particularly in terms of self-categorization approaches to identity.

The central implication is that these findings point to alternative strategies of self-categorization and comparison. Because of the intersecting ways blue-collar workers are subordinated (as described earlier), intergroup theory would predict one of three responses. First, individual group members may try to achieve social mobility by discursively, psychologically, or materially moving to a higher-status group. Second, the group may engage in social competition, in which members take part in collective social action to change negative perceptions and/or attitudes toward the group. Third, they may engage in social creativity whereby they change their point(s) of comparison (Tajfel \& Turner, 1979). More specifically, self-categorization theory would explain that individuals will engage in some form of cognitive comparison to enable ingroup members to construct a positive identity in comparison to the outgroup (Hogg \& Terry, 2001).

Yet instead of engaging in downward social comparisons these bluecollar workers do something distinctively different. Rather than directly engaging themselves in social group comparisons, they use implicit, unspoken, widely accepted comparisons in which mining fits in the middle. Below them, sewer workers have dirtier and more repulsive jobs and fast food workers have lower-paid and lower-skilled jobs. Above them, doctors, lawyers, and other professionals have highly paid jobs and more social status. From their position, they favorably evaluate and compare the two outgroups to engage in the process of their own self-enhancement (see Hogg \& Terry, 2001). By equating the lower and higher social groups 
as equally deserving of dignity and respect, they extend that same request for dignity to themselves. Consequently, their use of high-status and low-status outgroups enables them to redraw the boundaries around a new, broader, more inclusive category of working people. Moreover, in crafting a juxtaposition that backgrounds their own occupational group, they create a safe space from which they can call for more dignity without talking about and/or touching on the raw edges of their own identity tensions. Ultimately, they are able to position their own social status in a nonthreatening and insulated middle ground.

It is important to note the ironies in the treatment of outgroups in these discourses. Lower-status outgroup members (e.g., ditch diggers) typically were elevated. Participants frequently advocated for lowerstatus group members to "have as much dignity" as anyone else. They spoke at length of the value of these lower-status positions for society, the skill and care necessary to do these jobs well, and their view that these jobs are as "real" as any others. Therefore, the blue-collar participants were not engaging in social creativity only on behalf of their own group but also on behalf of a lower-status group. However, by the very nature of using the ditch digger group as a polarized point of comparison, they were insinuating a downward social comparison and tacitly acknowledging additional social stigma.

Their treatment of the higher-status outgroup (e.g., doctors) was far more complex and ambivalent, as this group's members were both disparaged and esteemed in the discourses (see Lamont, 2000). In terms of disparaging comments, high-status outgroup members were described as "highfalutin," "mucky-mucks," and "out to screw employees." Yet they also were revered at the same time. Participants expressed appreciation for the services these professionals provide and acknowledged the social desirability of such careers. This contradiction is necessary for the social comparison to be effective. In self-categorization terms, the disparaging remarks served the purpose of reducing the metadistance between the two outgroups such that - at least in terms of dignity - the distance between the groups becomes insignificant. Thus, a new, all-inclusive psychologically based group can be formed where everyone is equal (Turner $\&$ Oakes, 1989). However, the esteeming comments also are vital. If only the top group is "knocked down," then the status for all members of the new group is at risk of being lowered. Because people desire positive regard for themselves and their social groups, they also strive to retain as much dignity as possible; therefore, the status of the individuals in the upward comparison group must be preserved.

In short, the high-status/low-status juxtapositioning represents a complex renegotiation of meanings and social positions for all three 
groups and a more all-encompassing approach to identity construction. Therefore, this research adds to theory by demonstrating one way in which self-categorization processes can be more complex and nuanced than simple downward comparisons frequently reported in the literature.

\section{Implications for Practice}

While it has long been documented that blue-collar workers think of and value their work in largely instrumental terms (Thomas, 1989), it does not mean that they do not desire meaningful work and work experiences (see Cheney et al., 2008; Lucas \& Buzzanell, 2004). Although the participants may not have openly or directly talked about challenges to their own workplace experiences of (in)dignity, their central concerns still came through in their talk and pointed to problems they likely face on the job as they attempt to construct positive, dignified work identities.

First, blue-collar workers do not believe they are regularly considered by others to be valuable and important organizational members. In a society that tends to equate value with compensation, power, and credentials, it is not surprising to see that blue-collar employees and other low-status occupations are dismissed as less valuable (Berg \& Frost, 2005; Newman, 1999). Additionally, a focus on profit-generation and valueadded activity backgrounds the importance of core functions that often are taken for granted (e.g., janitorial services). Material differences (e.g., lower wages, fewer company perquisites, and higher rates of contingent employment arrangements) also contribute to blue-collar workers' perception of being valued less than other organizational members.

Second, they sense that their competence often is dismissed. As the population increasingly is attending and graduating from college, jobs that do not require higher levels of education are perceived not to require as much competence. For many blue-collar jobs, occupational requirements focus on physical strength rather than education or technical skills. Consequently, these workers may be seen as less competent than individuals who fill more specialized or technical positions. For instance, one participant who worked at the mine relayed a story about a supervisor telling him "even a monkey could do his job." Even though his bluecollar job (welding) required him to make a series of complex decisions and judgment calls to ensure the safety of himself and fellow miners, his specialized skills, training, and competence were disregarded by his supervisor.

Finally, they are hurt by disrespectful interpersonal treatment, especially when interactions emphasize status differences. While New- 
man (1999) points out that workers at the "bottom of the pyramid" in the United States' highly stratified occupational structure often bear the brunt of disrespectful interaction (e.g., fast-food workers facing insults, verbal ridicule, and harassment), blue-collar workers deal with a kind of disrespect that is far more subtle than bad manners. While the disrespect may not come in the form of verbal shout-outs, the snubbing received from higher-status members of society cuts deep, as ignoring and exclusion also are forms of incivility (Sypher, 2004).

Collectively, these insights point to implications for managers of a blue-collar workforce. First and foremost, it is important to understand that workplace dignity is a vitally important issue for blue-collar workers. Moreover, the negotiation of dignified workplace identities is shaped, in large part, by the contours of their unique work experiences. Therefore, managers could build dignity-rich worksites by learning more about the on-the-job experiences and meanings of work for blue-collar workers, nurturing organizational cultures that prioritize the dignity of workers, and investing in the ongoing development of best practices for creating and sustaining dignity in blue-collar workplaces.

\section{Conclusion}

In conclusion, these research findings reveal important insights into how blue-collar workers discursively construct a positive self-identity about their occupational and social positions. Furthermore, their discourses provide glimpses into highly salient, but often muted, sources of injury in terms of workplace dignity. Because blue-collar and working-class people represent a significant proportion of the workforce, understanding these discourses can have a large impact on managerial effectiveness.

Acknowledgments - An earlier version of this article was presented at the 2009 National Communication Association annual conference in Chicago. I would like to thank Jordan Soliz, Stacey Wieland, and the anonymous reviewers for Management Communication Quarterly for their constructive feedback and insights. This research was supported by a grant from the Purdue Research Foundation. 


\section{References}

Ailon-Souday, G., \& Kunda, G. (2003). The local selves of global workers: The social construction of national identity in the face of organizational globalization. Organization Studies, 24, 1073-1096.

Allen, B. J. (2000). "Learning the ropes": A black feminist standpoint analysis. In P. M. Buzzanell (Ed.), Rethinking organizational and managerial communication from feminist perspectives (pp. 177-208). Thousand Oaks, CA: Sage.

Alper, L. (Writer). (2005). Class dismissed: How TV frames the working class [Video]. United States: Media Education Foundation.

Alvesson, M., Ashcraft, K. L., \& Thomas, R. (2008). Identity matters: Reflections on the construction of identity scholarship in organization studies. Organization, 15, 5-28.

Alvesson, M., \& Willmott, H. (2002). Identity regulation as organizational control: Producing the appropriate individual. Journal of Management Studies, 39, 619-644.

Ashcraft, K. L. (2005). Resistance through consent? Occupational identity, organizational form, and the maintenance of masculinity among commercial airline pilots. Management Communication Quarterly, 19, 67-90.

Ashforth, B., \& Kreiner, G. E. (1999). "How can you do it?": Dirty work and the challenge of constructing a positive identity. Academy of Management Review, 24, 413-434.

Ashforth, B., \& Mael, F. (1989). Social identity theory and the organization. Academy of Management Journal, 14, 20-39.

Berg, P., \& Frost, A. C. (2005). Dignity at work for low wage, low skill service workers. Industrial Relations, 60, 657-682.

Bureau of Labor Statistics. (2010). Industries at a glance: Natural resources and mining. Retrieved from http://www.census.gov/ prod/2002pubs/01statab/labor.pdf

Cheney, G., Zorn, T. E., Planalp, S., \& Lair, D. J. (2008). Meaningful work and personal/social well-being: Organizational communication engages the meanings of work. In C. S. Beck (Ed.), Communication yearbook 32 (pp. 137-185). New York: Routledge.

Ciulla, J. B. (2000). The working life: The promise and betrayal of modern work. New York: Times Books.

Clair, R. P. (1996). The political nature of the colloquialism, "a real job": Implications for organizational socialization. Communication Monographs, 63, 249-267.

Dufur, M. J., \& Feinberg, S. L. (2007). Artificially restricted labor markets and worker dignity in professional football. Journal of Contemporary Ethnography, 36, 505-536. 
Dutton, J. E., Roberts, L. M., \& Bednar, J. (2010). Pathways for positive identity construction at work: Four types of positive identity and the building of social resources. Academy of Management Review, 35, 265-293.

Gibson, M. K., \& Papa, M. J. (2000). The mud, the blood, and the beer guys: Organizational osmosis in blue-collar work groups. Journal of Applied Communication Research, 28, 68-88.

Gilbert, D. (2008). The American class structure in an age of growing inequality (7th ed.). Thousand Oaks, CA: Sage.

Hodson, R. (2001). Dignity at work. Cambridge, UK: Cambridge University Press.

Hogg, M. A. (2006). Social identity theory. In P. J. Burke (Ed.), Contemporary social psychological theories (pp. 111-136). Stanford, CA: Stanford University Press.

Hogg, M. A., \& Terry, D. J. (2001). Social identity theory and organizational processes. In M. A. Hogg \& D. J. Terry (Eds.), Social identity processes in organizational contexts (pp. 1-12). Philadelphia: Psychology Press.

Jorgenson, J. (2002). Engineering selves: Negotiating gender and identity in technical work. Management Communication Quarterly, 15, 350-380.

Kaufman, P. (2003). Learning to not labor: How working-class individuals construct middle-class identities. Sociological Quarterly, 44, 481-504.

Keyton, J., Ferguson, P., \& Rhodes, S. C. (2001). Cultural indicators of sexual harassment. Southern Communication Journal, 67, 33-50.

Korczynski, M. (2003). Communities of coping: Collective emotional labour in service work. Organization, 10, 55-79.

Lamont, M. (2000). The dignity of working men: Morality and the boundaries of race, class, and immigration. Cambridge, MA: Harvard University Press.

Lawless, J., \& Moss, C. (2007). Exploring the value of dignity in the worklife of nurses. Contemporary Nurse, 24, 225-236.

Lindlof, T. R. (1995). Qualitative communication research methods. Thousand Oaks, CA: Sage.

Lucas, K. (2010, April). A cross-cultural perspective on communication and workplace dignity. Paper presented at the Central States Communication Association annual meeting, Cincinnati, $\mathrm{OH}$.

Lucas, K., \& Buzzanell, P. M. (2004). Blue-collar work, career, and success: Occupational narratives of sisu. Journal of Applied Communication Research, 32, 273-292.

Lucas, K., \& Steimel, S. (2009). Creating and responding to the gen(d)eralized other: Women miners' community-constructed identities. Women's Studies in Communication, 32, 320-347.

Lutgen-Sandvik, P. (2006). Take this job and ... : Quitting and other forms 
of resistance to workplace bullying. Communication Monographs, 73, 406-433.

Lutgen-Sandvik, P. (2008). Intensive remedial identity work: Responses to workplace bullying trauma and stigmatization. Organization, 15, 97-119.

McGuire, T., Dougherty, D. S., \& Atkinson, J. (2006). "Paradoxing the dialectic": The impact of patients' sexual harassment in the discursive construction of nurses' caregiving roles. Management Communication Quarterly, 19, 416-450.

Meares, M. M., Oetzel, J. G., Torres, A., Derkacs, D., \& Ginossar, T. (2004). Employee mistreatment and muted voices in the culturally diverse workplace. Journal of Applied Communication Research, 32, 4-27.

Miles, M. B., \& Huberman, A. M. (1994). Qualitative data analysis: An expanded sourcebook (2nd ed.). Thousand Oaks, CA: Sage.

Mishel, L., Bernstein, J., \& Shierholz, H. (2009). The state of working America 2008/2009. Ithaca, NY: ILR Press.

Newman, K. S. (1999). No shame in my game: The working poor in the inner city. New York: Russell Sage.

Owen, W. F. (1984). Interpretive themes in relational communication. Quarterly Journal of Speech, 70, 274-287.

Pal, M., \& Buzzanell, P. M. (2008). The Indian call center experience: A case study in changing discourses of identity, identification, and career in a global context. Journal of Business Communication, 45, 31-60.

Pepper, G. L., \& Larson, G. S. (2006). Cultural identity tensions in a postacquisition organization. Journal of Applied Communication Research, 34, 49-71.

Perrucci, R. L., \& Wysong, E. (2003). The new class society: Goodbye American dream? (2nd ed.). Lanham, MD: Rowman and Littlefield.

Purser, G. (2009). The dignity of job-seeking men: Boundary work among immigrant day laborers. Journal of Contemporary Ethnography, 38, 117139. doi: $10.1177 / 0891241607311867$

Scott, C. R. (2007). Communication and social identity theory: Existing and potential connections in organizational identification research. Communication Studies, 58, 123-138.

Sypher, B. D. (2004). Reclaiming civil discourse in the workplace. Southern Communication Journal, 69, 257-269.

Tajfel, H., \& Turner, J. C. (1979). An integrative theory of intergroup conflict. In W. G. Austin \& S. Worchel (Eds.), The social psychology of intergroup relations (pp. 33-47). Monterey, CA: Brooks-Cole.

Thomas, R. J. (1989). Blue-collar careers: Meaning and choice in a world of constraints. In M. B. Arthur, D. T. Hall, \& B. S. Lawrence (Eds.), Handbook of career theory (pp. 354-379). Cambridge, UK: Cambridge University Press. 
Tracy, S. J., \& Scott, C. (2006). Sexuality, masculinity, and taint management among firefighters and correctional officers. Management Communication Quarterly, 20, 6-38.

Turner, J. C., \& Oakes, P. J. (1989). Self-categorization theory and social influence. In P. B. Paulus (Ed.), Psychology of group influence (2nd ed., pp. 233-275). Hillsdale, NJ: Lawrence Erlbaum.

Weitzman, E. A., \& Miles, M. B. (1995). Computer programs for qualitative data analysis: A software sourcebook. Thousand Oaks, CA: Sage.

Wolcott, H. F. (1994). Transforming qualitative data: Description, analysis, and interpretation. Thousand Oaks, CA: Sage.

Zoller, H. M. (2003). Health on the line: Identity and disciplinary control in employee occupational health and safety discourse. Journal of Applied Communication Research, 31, 118-139.

Zweig, M. (2000). The working class majority: America's best kept secret. Ithaca, NY: ILR Press.

\section{xx}

Kristen Lucas (PhD, Purdue University) is an assistant professor in the Department of Communication Studies at the University of NebraskaLincoln, 436 Oldfather Hall, Lincoln, NE 68588; email klucas3@unl.edu. Her main research interests center on workplace dignity and career discourses. 